\title{
Breeze Circulation in the Crimean Region Atmosphere
}

\section{V.V. Efimov, O.I. Komarovskaya}

\author{
Marine Hydrophysical Institute, Russian Academy of Sciences, Sevastopol, \\ Russian Federation \\ e-mail: vefim.38@mail.ru
}

\begin{abstract}
Using the numerical model WRF-ARW, the atmospheric circulation in the Crimea region in a summer period is simulated with the purpose of distinguishing contribution of the breeze circulation conditioning the wind speed. The values of the breeze speed at day and night are shown for the moments when they achieve their maximum, i.e. at 1 p.m. and 2 a.m., local time, respectively. Under the assumption of a breeze daily quasi-periodicity, the speeds of the day and night breeze are calculated for the whole region and, in more details, - for several regions of the Crimea coast. As the insolation daily cycle which is of insignificant inter-annual variability in a summer period, constitutes the initial reason of breeze circulation, its obtained estimates can be attributed rather surely to the specified period of a year. The typical form of a daily breeze circulation over the Crimea is the directed to the peninsular center surface wind conditioned by two features of the region: the limited dimensions of the Crimea Peninsula and presence of the sufficiently high Crimean Mountains. Three areas with the increased values of a day breeze are distinguished: the western coast (the Sevastopol Evpatoria region), the northwestern coast and the mountain foot zone of the Crimea Southern coast. The features of the day and night breeze formation are selected in these regions. Presence of the littoral mountains and the coast configuration result in formation of the breeze development specific features.
\end{abstract}

Keywords: breeze, numerical modeling, atmospheric circulation, the Crimea region.

DOI: 10.22449/1573-160X-2015-6-69-78

(C) 2015, V.V. Efimov, O.I. Komarovskaya

(C) 2015, Physical Oceanography

Introduction. It is known that in the atmospheric boundary layer of the Black Sea region with its complicated orography, underlying surface discontinuities and the land - the sea thermal contrasts a wide spectrum of mesoscale processes is developed. Breeze circulation, different kinds of mountain winds in the coastal areas of the sea (such as bora), mesoscale eddies and some others processes could be attributed to them. At the same time their spatio-temporal structure hasn't been studied enough.

The characteristic feature of the region atmospheric processes in springsummer period is a breeze circulation connected with the diurnal cycle of thermal contrasts between the land and the sea. Lesser thermal capacity of the land in comparison with the sea causes its more rapid radiant heating during the daylight period and the increase of temperature and pressure gradients in the atmosphere between the land and the adjoined sea. In general, the sea breeze is a gravity flow of the cold sea air distributing at the land. In the forepart of this flow the raised "head" of the breeze with the ascending air flow is formed. This above-the-land gravity flow is located in the lower part of the atmosphere boundary layer. Above it the indirect breeze circulation cell (which is less localized by the height) is formed. The border of section between the direct and indirect cells could be unstable and it leads to the occurrence of the Kelvin - Helmholtz type oscillations. The sea breeze propagates on the land over a distance of $50-100 \mathrm{~km}$. By the end of the daylight hours the gravity flow decays. At the same time, the formed breeze "head" is able to generate the bore (solitary internal wave) propagating to the land at 200 - 
$300 \mathrm{~km}$ distance. During the daytime warming in the area of breeze flow above the land the well-developed convection is set. Unlike the sea breeze, the land breeze caused by the increased (in comparison with the sea) radiative land cooling develops weaker. This asymmetry is connected with a number reasons and foremost with lesser (in comparison with the day) night temperature contrast between the land and the sea.

Breeze circulation has a significant effect on the coastal region climate formation. The sea breeze is a main mechanism of ventilation above large maritime cities, as well as the main source of the moisture and air-cooling in the afternoon in the land coastal areas with Mediterranean or tropical climates. The breeze also affects the operation of wind-powered generators located in the coastal areas.

Over the last $10-20$ years the breeze circulation has been extensively studied (survey works [1, 2]). For example, the number of studies on the breezes (according to the article [2]), published only in $1990-2003$ is more than 500 . Essentially, the problem of the breeze circulation studying includes a wide range of issues related to the nonlinear interaction from the synoptic (hundreds of kilometers) to the mesoscale and small scale. Even in the aforementioned general idea of breeze as a gravitational flow of cold sea air in practical applications should be also considered the effect of the Coriolis force, coastline nonlinearity, and heterogeneity of coast topography, synoptic conditions (especially the background wind, its direction and intensity) and other physical effects.

Significant progress in the study of the physical mechanisms and properties of breeze circulation occurred due to the usage of LES-approximations (Large Eddy Simulation) during the numerical modeling. They allowed to reproduce the smallscale breeze structure (in the model formulations) and to suggest new parameterizations of the breeze characteristics in the development process - its height, horizontal and vertical velocities [3-8].

The number of the works on numerical simulation of breeze circulation directly for the specific coastal areas is relatively small. For the Black Sea region they are practically absent (we should mention only the work [9] where the breeze for the Black Sea was calculated, but in the model with rather rough spatial grid, and the article [10] where the breeze above the Crimea was considered). At the same time, such numerical calculations for the Black Sea with its complex coastline and the presence of high coastal mountains are of undoubted interest, and the calculation results may differ significantly from the simple model representations.

This work is based on the atmospheric circulation simulation using the regional numerical modeling with the increased spatial resolution for 31-days period - the period of the breeze greatest development in the Black Sea region. As the continuation of the work [9], the contribution of the breeze circulation for the daily and nightly periods of day's cycle for the entire Crimean region and, in more details, for several areas with different coast configuration and land topography was marked out. The features of the breeze development in these regions are considered.

Numerical model. The purpose of the numerical modeling in this work is the reproduction of breeze circulation throughout the Black Sea region to get the averaged assessments for the sufficient time period in summer season. Therefore the known numerical model of atmosphere circulation WRF-ARW [11] with three imbedded domains, which parameters were selected to perform a long-term calculation with the increased spatial resolution and the necessary settings of physical parameters parameterization (primarily during the parameterization of 
atmospheric convective boundary layer) was used. Now we'll mention just the main of them.

Vertically there were $26 \sigma$-levels set unevenly arranged by the height in the planetary boundary layer. The resolution in the domains was 9,3 and $1 \mathrm{~km}$. The following parameterization schemes were used: RRTM (Rapid Radiative Transfer Model) and Dudhia to calculate the radiation balance of short-wave and long-wave radiation respectively, Kain - Fritsch - to calculate the cumulus clouds. To describe the phase transitions in the atmosphere (microphysical processes) the Single-Moment 3-class scheme was used.

For the parameterization of the surface boundary layer friction MM5 similarity scheme was used. The atmospheric boundary layer was described by the YSU (Yonsei University) scheme. In this scheme the linear-parabolic profile of vertical turbulent viscosity coefficient is prescribed, and for the parameterization of subgrid fluxes of momentum, heat and moisture, which are not resolved in the model, the correction of the local gradient is introduced, and the magnitude of the involvement flow is prescribed.

The FNL (Global Final Analyses) operational analysis data with $0.5 \times 0.5^{\circ}$ resolution, which had been updated every 6 hours, were used as an input. After the adaptation of the model to the initial conditions, the development of atmospheric processes in all the domains was determined only by the periodically updated input data predetermining the boundary conditions on the external domain.

The modeling results. For the calculations the 31-day summer period from July 6 to August 6, 2011 was chosen. In Fig. 1 the change of the wind velocity at $10 \mathrm{~m}$ height for the chosen period at the point in the central part of the peninsula with $45^{\circ} \mathrm{N}, 34^{\circ} \mathrm{E}$ coordinates is represented. In general, this period was characterized by a relatively weak synoptic variability, the short wind gusts with $8-9 \mathrm{~m} / \mathrm{s}$ velocity were observed just for $2-3$ days, at the rest of time the wind velocity was within 5 $7 \mathrm{~m} / \mathrm{s}$ limits. Considering the breeze quasi-periodicity, the selection of breeze circulation contribution, which has $\sim 4 \mathrm{~m} / \mathrm{s}$ characteristic velocity values on a background of the same or larger velocities of the synoptic wind, was achieved by a simple procedure of velocity values averaging for the predetermined time of the day with the subsequent subtraction of the average monthly values. This allowed us to calculate the daily cycle of breeze development. The mentioned averaging procedure allowed us to select the average monthly contribution of the breeze circulation at the background of the current synoptic wind, which has $3-5$ days characteristic time scales of variability (assuming their additivity). Although, the calculated values are the average monthly values of breeze velocity for the selected time period, the effect of the synoptic processes (of this period) on the breeze circulation assessment could not be considered as negligible.

The fields of breeze circulation velocity at $10 \mathrm{~m}$ height are the result of such calculations, and it is represented in Fig. 2, $a, b$. The velocities of the sea and land breezes for the moment of their maximum development at 13 and 2 am (local time) respectively are shown. As far as the initial cause of the breeze circulation is an insolation diurnal cycle, which has a small interannual variability in the summer period, the obtained assessments of breeze circulation could be confidently referred to the mentioned period of year. The main reason for violations of the diurnal solar radiation cycle near the surface in the summer period for the Black Sea basin is a penetration of cyclones. But such events for summer are quite rare. For example, for the July, averagely, not more than one case per month with the duration up to 2 - 3 days, when the cloud cover over the sea makes up $70-100 \%$ (in this case the breeze doesn't develop) is observed. For the period of our calculations there was only a minor episodic cloudiness observed over the sea 
(http://rapidfire.sci.gsfc.nasa.gov/imagery/subsets/). Therefore, the given breeze velocity fields may be considered as typical for the Crimean region for this season.

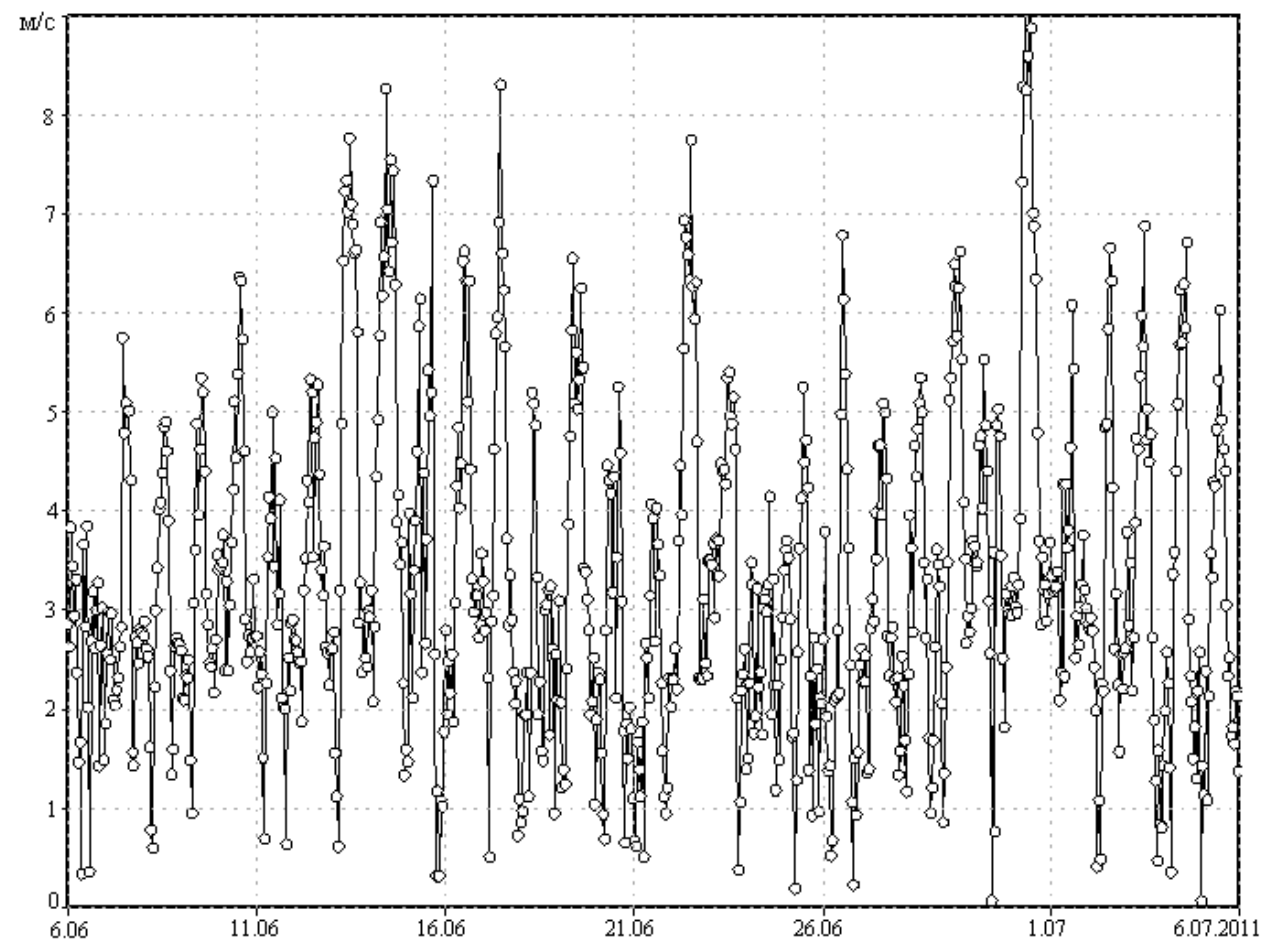

Fig. 1. The graph of wind velocity at $10 \mathrm{~m}$ height for July 6 - August 6,2011 in the point with $45^{\circ} \mathrm{N}$, $34^{\circ} \mathrm{E}$

As is evident from Fig. 2, the breeze velocity field is determined by two features of the region: by the limited size of the Crimean Peninsula and the presence of sufficiently high Crimean mountains. Three areas of increased wind velocities of the sea breeze are distinguished. They are the following: West coast (Sevastopol - Yevpatoria region), the North-East coast and the foothill zone of the Southern coast of the Crimea (Fig. 2, a). Here the values of the sea breeze velocities near the coast are maximal and amount $\sim 4 \mathrm{~m} / \mathrm{s}$. Overall, the picture of the sea breeze velocity field has a character of air currents converging to the centre of the peninsula. We shall notice that the result of this is the increased precipitation level and cloudiness in the central regions of the Crimea in comparison with the coastal regions. By the direction and areas of maximum velocities localization the land breeze is opposite to the sea breeze (Fig. 2, $b$ ).

In Fig. 3, $a, b$ the fields of the breeze velocity fields for the southern part of the peninsula are shown. It is obvious that the velocity here is determined by the character of the relief. In general, the sea breeze in this part of the peninsula has a form of the air currents converging to the peaks of the Crimean Mountains, and the land breeze - the form of currents flowing down from the slopes of the mountains. The characteristic small-scale features related to the mountainous relief are imposed on a general quasi-diurnal variability of the wind velocity vector. Thus, it is possible to select Yalta region where the increased wind velocities occur on the southern slopes of the high surrounding mountains, and Alushta region where the greater wind velocities are related to the lowering of the mountain ridge - Angarskyi Pass. 

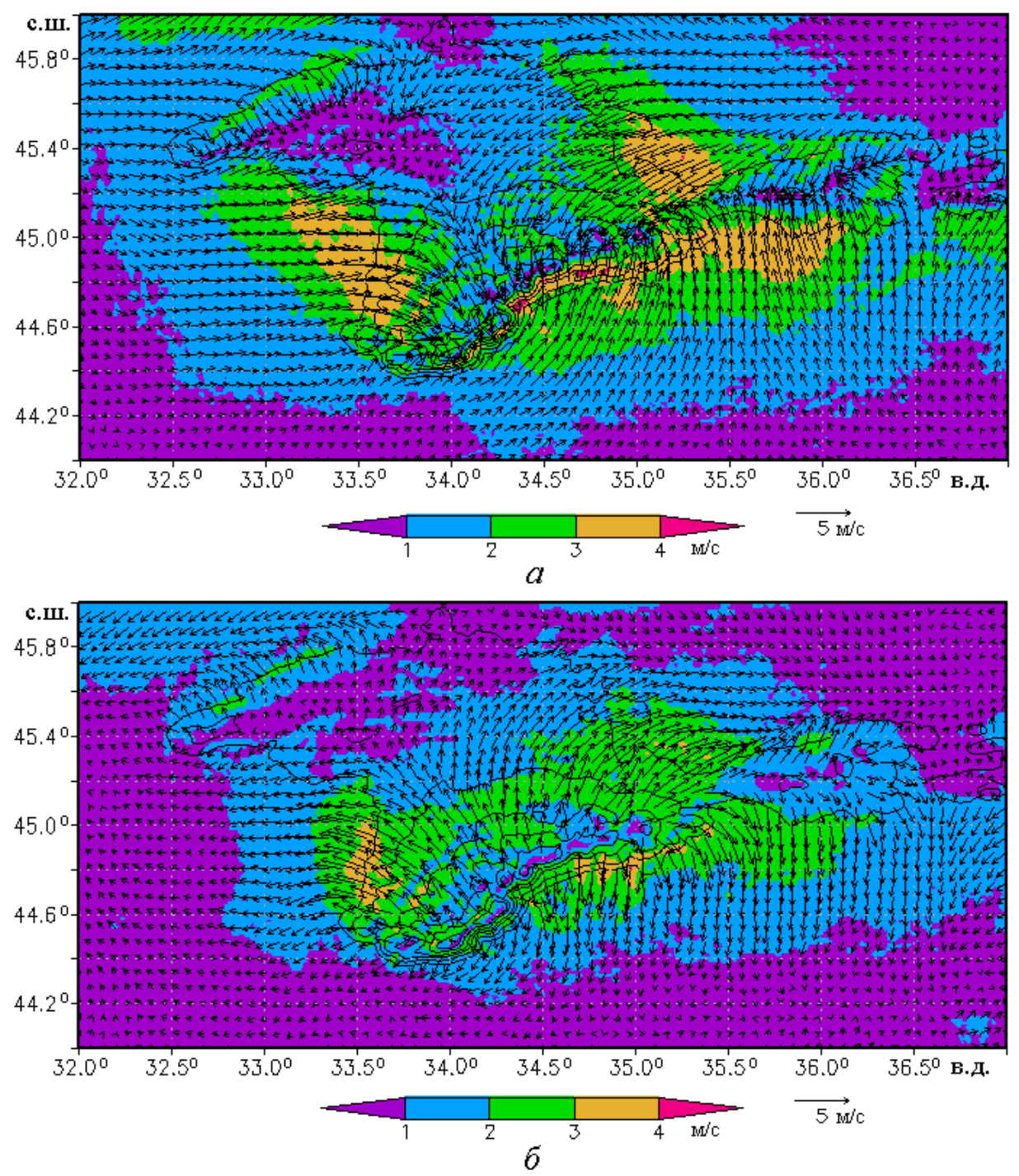

Fig. 2. The fields of wind velocity for the sea breeze $(a)$ for the moment of its maximum development $(1.00$ p.m) and for the land breeze $(b)$ for the moment of its maximum development (2.00 a.m) for the Crimean region (the value of wind velocity modulus is shown by the colors)

As it was mentioned, the calculated velocity values are the average monthly assessments, so it is interesting to introduce the correction and to identify the contribution to the velocity field of "clear" breeze circulation, which develops in the conditions of a small synoptic wind, i. e. to eliminate during the averaging procedure the days when the breeze didn't develop. For our case there were the days with the strong synoptic background wind. In the first approximation it may be considered that the breeze circulation diurnal cycle is violated with the background wind velocities exceeding some boundary value: when the velocities of the wind blowing from the land to the sea are greater than $5 \mathrm{~m} / \mathrm{s}$, the breeze over the land doesn't develop [12]. With the same velocities of the wind blowing from the sea to the land, the area of breeze circulation shifts far to the land. In both cases PHYSICAL OCEANOGRAPHY NO. 6 (2015) 
it could be considered that the breeze develops with the small wind velocity - up to $\sim 5 \mathrm{~m} / \mathrm{s}$. Having designed a histogram of wind velocities it becomes easy to assess the portion of the days in a monthly interval with the wind velocities exceeding this boundary value. Without illustrating, we should specify that this value was about $\sim 20-30 \%$. It means that for the estimation of the "clear" breeze velocities the data from Fig. 1 should be multiplied by $1.3-1.4$.
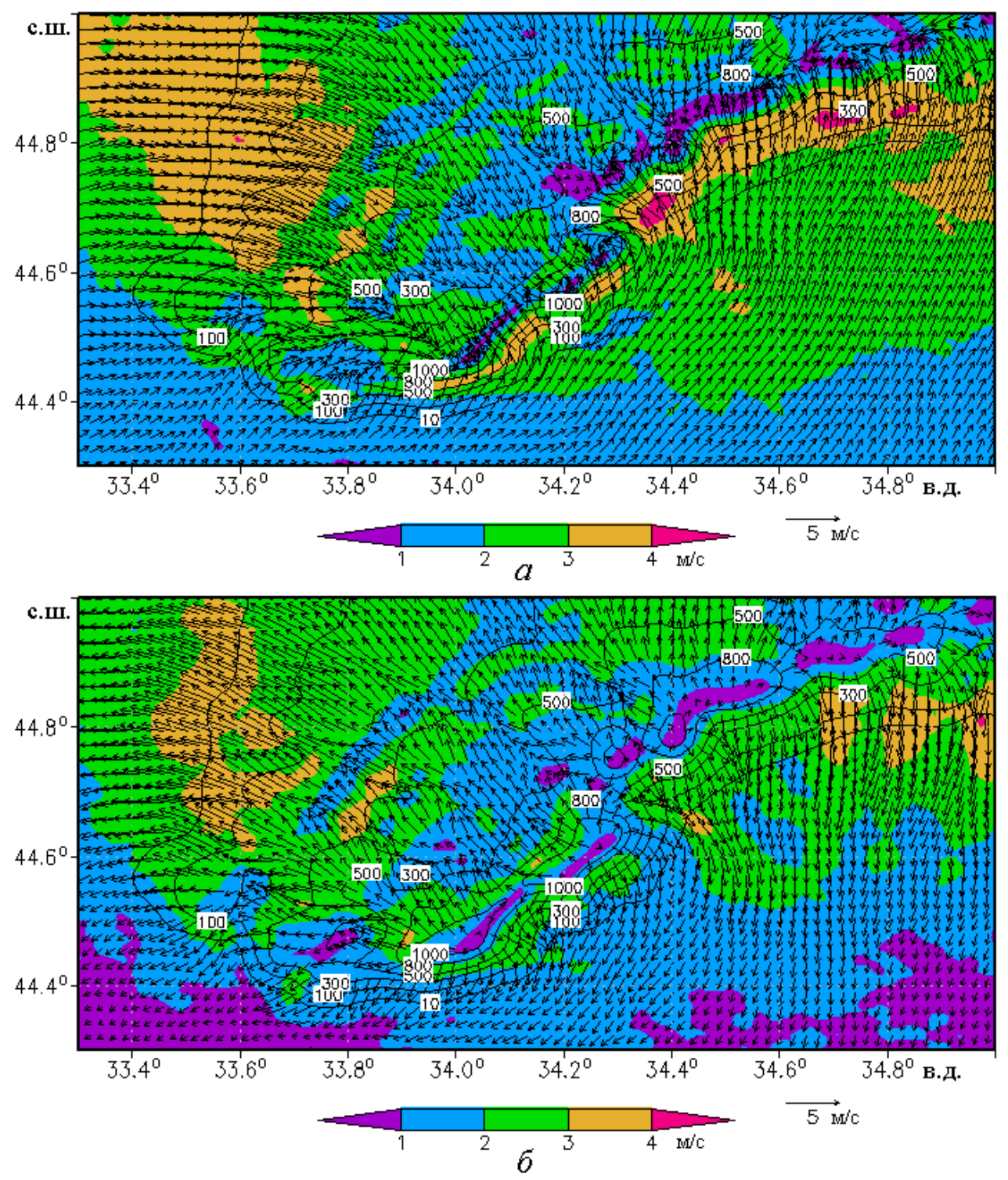

Fig. 3. The fields of wind velocities for the sea breeze $(a)$ for the moment of its maximal development $(1.00 \mathrm{p} . \mathrm{m})$ and the land breeze $(b)$ for the moment of its maximal development $(2.00 \mathrm{a} . \mathrm{m})$ for the Southern part of the Crimea (the value of wind velocity modulus is shown by the colors; the numbers in the frames - the relief, $\mathrm{m}$ ) 
In Fig. 4 and 5 the velocities of the sea and land breezes and the loci of the breeze circulation velocities for several regions of the Crimea are given. The circulation in the western regions with the absence of mountains and with the straight-line coast has more simple form. In the longitudinal section along $44.8^{\circ} \mathrm{N}$ (Fig. 4, $a$ ) where the velocities of the sea and land breezes for the moment of their maximum development are shown, it is obvious that the sea breeze distributes to the land at more than $50 \mathrm{~km}$ distance, and the land breeze - at 30 - $40 \mathrm{~km}$ distance. At the same time the land breeze velocity is somewhat lower than the sea breeze velocity. The breezes affected by the relief (the Crimean Mountains) attenuate over the land more rapidly. In Fig. 4 it could be seen that the breeze velocity at the day is greater than at night as over the sea as over the land. It should be mentioned that the main reason for the land breeze decreased velocities is smaller temperature drop between the land and the sea, which in our case makes up $5-6{ }^{\circ} \mathrm{C}$ for the period of the land breeze maximum development in comparison with $9-10{ }^{\circ} \mathrm{C}$ for the sea breeze. Besides, the asymmetry of the land and the sea breeze velocities may occur due to the differences of atmosphere boundary layer stratification and the turbulent viscosity coefficients [13].

It is known that near the surface the breeze circulation is not just a simple unidirectional flow. So far as the time scale of its development could be compared with the Coriolis force scale, it is sufficiently affected by the Earth revolution. In Fig. 5 the diurnal breeze velocity loci for several points of region are shown. For Yevpatoria, which is situated on a plain coast (Fig. 5, a), locus has a more simple form. The clockwise direction change of wind velocity vector related to the Coriolis force [14 - 16] is clearly represented here. For other regions of the coast the loci have more complicated form.

For Sevastopol, situated in the south-west of the Crimea, the locus has a figure of eight, the predominating breeze direction is to the West and to the East with small velocity vector fluctuations between them (Fig. $5, b$ ).

As it was mentioned, the breeze circulation over the whole southern land part of the peninsula is affected by the Crimean Mountains. It could be clearly seen in the meridional section along $34^{\circ} \mathrm{E}$, which crosscut the central part of the ridge (Fig. $4, b$ ). The velocities of surficial wind are determined by the mountain relief: at the day and night the breeze wind above the peak is practically absent and it develops on the both slopes of the ridge. Generally speaking, such wind on the mountain slopes can't be considered as the breeze wind (i.e. related with the heat contrast between the land and the sea), but it should be considered as a mountain slope wind conditioned by the diurnal radiant heating of the mountain slopes surface. At night this slope wind can be considered as katabatic wind [17]. For Yalta at the Southern coast of the Crimea (Fig. 5, c) the locus is formed by the predominating sea breeze, which blows from the sea to the mountains.

In Fig. 4, $c$ the breeze velocities along $35.5^{\circ} \mathrm{E}$ meridional section are shown. The velocity field of breeze circulation here is determined by the summarized effect of the heat contrasts between the seas (the Black Sea and the Azov Sea) and land part of the peninsula. At the day the breeze wind blows to the center of isthmus, at night - from the center to the sea (Fig. 2, b). As the result, the breeze velocity minimum is formed over the land part of the section (Fig. 4, $c$ ). 

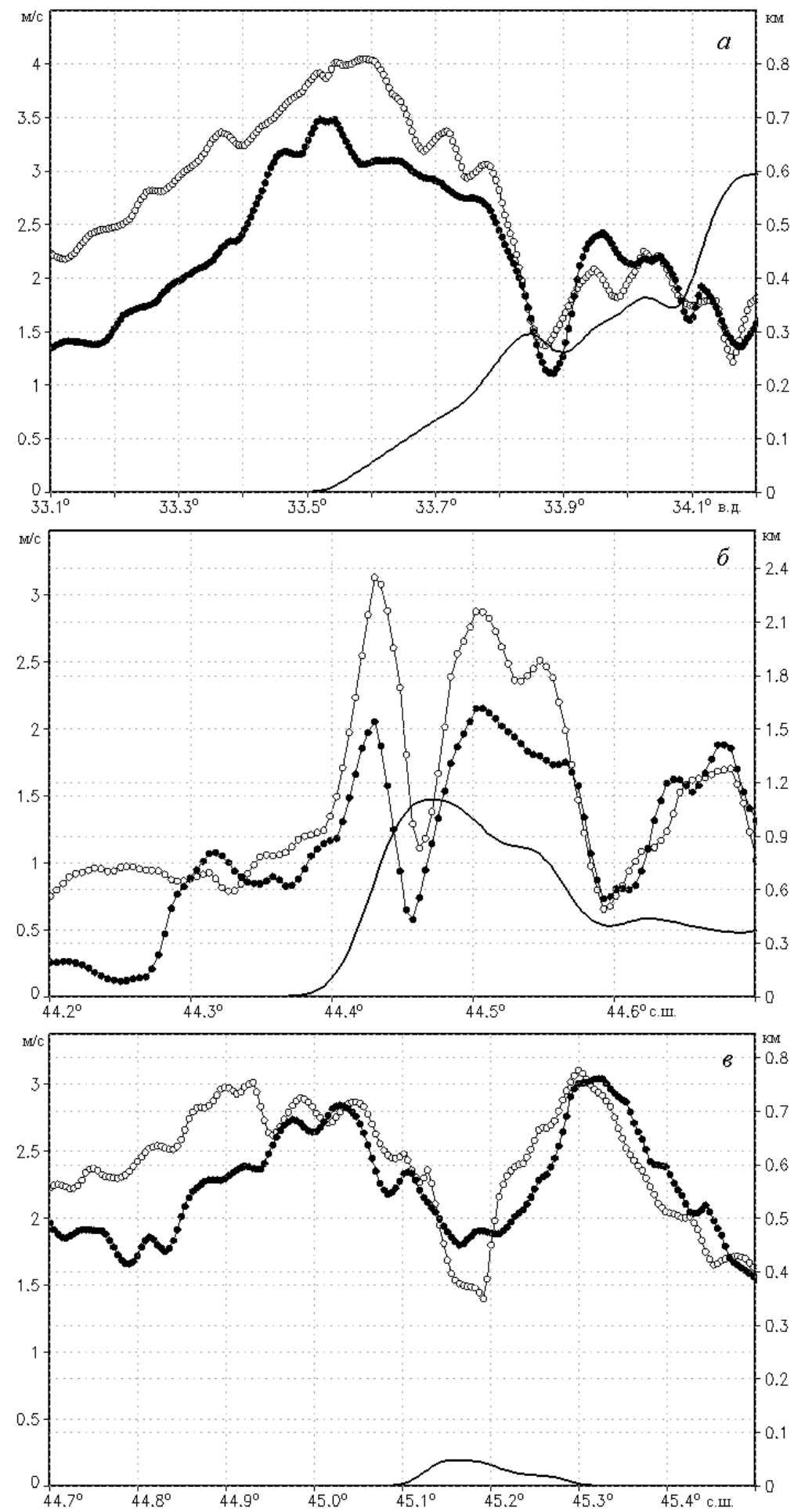

Fig. 4. The graphs of the sea $(-0-)$ and the night $(-\bullet-)$ breezes in the section, which goes along $44.8^{\circ} \mathrm{N}(a)$ and in meridional sections by $34^{\circ} \mathrm{E}(b)$ and $35.5^{\circ} \mathrm{E}(c)$ for the moment of their maximum development (land relief along the section is represented by a solid line) 

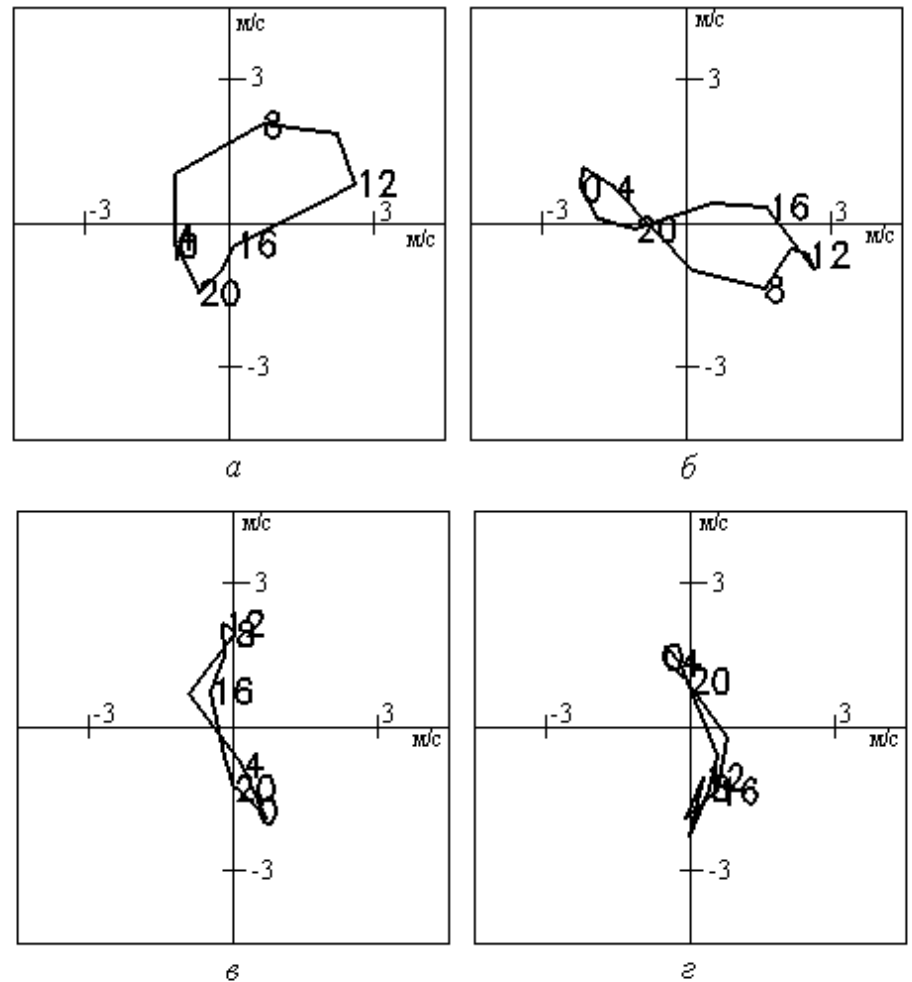

Fig. 5. Diurnal breeze velocity loci for Yevpatoria (a), Sevastopol (b), Yalta (c) and Simferopol (d) (the orientation of axes matches the geographical directions)

The wind velocity locus for Simferopol, i.e. for the coast-remoted part of the peninsula (Fig. $5, d$ ) is formed by the sea breeze flows converging from the coast to the center and by the night slope winds from the Crimean Mountains.

Conclusion. The numerical simulation of the atmospheric circulation in the Crimean region for 31-day period in summer was performed to select the breeze circulation contribution. Under the assumption about the breeze diurnal quasiperiodicity the velocities of the sea and the land breezes for the entire region and (more detailed) for several coastal areas were calculated. The characteristic form of the sea breeze circulation is a surficial wind directed to the center of the peninsula and determined by two region features: the limited size of the Crimean Peninsula and the presence of the sufficiently high Crimean Mountains. Three areas of increased wind velocities of the sea breeze are distinguished. They are the following: the West coast (Sevastopol - Yevpatoria region), the North-East coast and the foothill zone of the Southern coast of the Crimea (Fig. 1, a). For the West coast in the area of the rectilinear coast the breeze circulation has more simple form: the velocity loci approximate the elliptical form (greater sea breeze velocities over the land and the sea in comparison with the land breeze velocities). Above the sea the breeze distributes at $30-50 \mathrm{~km}$ distance and the breeze distribution above the land occurs in accordance with the relief features.

The process of breeze circulation in other areas of the Crimean region is affected substantially by the surrounding mountains and coastline inhomogeneity. PHYSICAL OCEANOGRAPHY NO. 6 (2015) 
In the area of the Southern Coast of the Crimea sea breeze is blocked by the high Crimean Mountains and a land breeze has a character of katabatic flow from the mountain ridge. Both sea and land breezes above the sea in this part of the peninsula are determined foremost by fine-scale inhomogeneities of coastline and adjoining mountains. In the eastern part of the Crimean Peninsula the breeze is determined by the joint effect of the Black Sea and the Azov Sea and also by coast contour features.

\section{REFERENCES}

1. Crosman, E.T., Horel, D.J., 2010, “Sea and lake breezes: A review of numerical studies", Bound.-Lay. Met., vol. 137, no. 1, pp. 1-29.

2. Miller, S.T.K., Keim, B.D., Talbot, R.W. [et al.], 2003, "Sea breeze: structure, forecasting, and impacts”, Rev. Geophys., vol. 41, no. 3 / 1011, pp. 1-31.

3. Antonelli, M., Rotunno, R., 2007, "Large-eddy simulation of the onset of the sea breeze", J. Atmos. Sci., vol. 64, no. 12, pp. 4445-4457.

4. Liu, C., W., Moncrieff, M., 2000, "Simulated density currents in idealized stratified environments”, Mon. Wea. Rev., vol. 128, no. 5, pp. 1420-1437.

5. Porson, A., Steyn, D.G., Schayes, G., 2007, "Sea-breeze scaling from numerical model simulation. Part I: Pure sea breezes”, Bound.-Lay. Met., vol. 122, no. 1, pp. 17-29.

6. Porson, A., Steyn, D.G., Schayes, G., 2007, "Sea-breeze scaling from numerical model simulation. Part II: Interaction between the sea breezes and slope flows”, Bound.-Lay. Met., vol. 122, no. 1, pp. 31-41.

7. Robinson, F.J., Patterso, M.D., Sherwood, S.C., 2013, "A numerical modeling study of the propagation of idealized sea-breeze density currents”, J. Atmos. Sci., vol. 70, no. 3, pp. 653-668.

8. Sha, W., Kawamura, T., 1991, "A numerical study of sea/land breezes as a gravity currents: Kelvin-Helmholtz billows and inland penetration of the sea-breezes front”, J. Atmos. Sci., vol. 14, no. 14, pp. 1649-1665.

9. Efimov, V.V., Barabanov, V.S., Krupin, A.V., 2012, “Modelirovanie mezomasshtabnykh osobennostey atmosfernoy tsirkulyatsii v Krymskom regione Chernogo morya [Simulation of atmospheric circulation mesoscale circulation in the Crimean region of the Black Sea]", Morskoy gidrofizicheskiy zhurnal, no. 1, pp. 64-74 (in Russian).

10. Efimov, V.V., Barabanov, V.S., 2009, "Brizovaya tsirkulyatsiya v Chernomorskom regione [Breeze circulation in the Black Sea region]”, Morskoy gidrofizicheskiy zhurnal, no. 5, pp. 2336 (in Russian).

11. Skamarock, W.C., Klemp, J.B., Dudhia, J. [et al.], 2008, “A Description of the Advanced Research WRF Version 3. NCAR technical note NCAR/TN -475+STR”.

12. Porson, A., Steyn, D.G., Schayes, G., 2007, "Formulation of an index for sea breezes in opposing winds”, J. Appl. Met. Climat., vol. 46, no. 8, pp. 1257-1263.

13. Mak, M.K., Walsh, J.E., 1976, “On the relative intensities of sea and land breezes”, J. Atmos. Sci., vol. 39, no 2, pp. 242-251.

14. Haurwitz, B., 1946, “Comments on the sea-breeze circulation”, J. Meteorol., vol. 4, no. 1, pp. 1-7.

15. Neumann, J., 1077, “On the rotation rate of the direction of sea and land breezes”, J. Atmos. Sci., vol. 34, no. 12, pp. 1913-1917.

16. Simson, J.E., 1996, "Diurnal changes in sea-breeze direction”, J. Appl. Met., vol. 35, no. 7, pp. 1166-1169.

17. Grisogono, B., 2003, "Post-onset behavior of the katabatic flow”, Bound.-Lay. Met., vol. 107, no. 1, pp. 17-29. 